\title{
PARTICIPATIVE MANAGEMENT OF ACADEMIC MOBILITY IN PHYSICAL CULTURE AND SPORT ACTIVITIES
}

\author{
S.L. Suvorova, alex97@shadrinsk.net, \\ I.S. Osipova, i.s.osipova@mail.ru \\ Shadrinsk State Pedagogical University, Shadrinsk, Russian Federation
}

\begin{abstract}
The article studies the support possibility for students' academic mobility in the sphere of physical culture and sports, based on the participative approach to students' academic mobility management. The concepts of "participation", "participative management", "academic mobility" were analyzed; a system of principles of the participative approach to managing the process of academic mobility of students were characterized. The literature review on the implementation of mechanisms for participative management of the students' academic mobility was presented. Particular attention is paid to the implementation of the students' academic mobility in physical culture and sports on the basis of participative management. The authors concluded that academic mobility can be viewed as the means of developing and updating the educational process and programs of higher education in Russia.

Keywords: participative approach, participative management, academic mobility, participative management of academic mobility in physical culture and sport activities.
\end{abstract}

\section{Problem}

The main principle of the modern system of higher education, in general, and in the sphere of physical culture and sports, in particular, is the principle of orientation to the personal success of a specialist - ensuring the professional growth of a person, his progress on the career ladder and economic viability. The main condition for the realization of this principle is individualization and increasing the flexibility of the educational process. At the level of educational programs, this means a transition to a modular structure and a flexible system for recording educational achievements, at the structural level it provides the opportunity for training in several institutions and the inclusion of the informal sector (short courses, training centers, corporate systems training and further training) in the education sector.

Another condition for the implementation of this principle is the development of the education content with a shift towards the formation of personal and professional competencies. The efforts of European countries and Russia in such areas as the development of academic mobility, the support of distance education, the creation of a single qualification system, quality monitoring and, in general, the realization of the idea of a unified European educational space are aimed specifically at individualization and increasing the flexibility of the educational process.

The priority is to support the academic mobility of students. Individual academic mobility is the temporary transfer of a student or employee for a certain period to another educational institution (at home or abroad) for teaching, conducting research or continuing education, after which the student, teacher, researcher or administrator returns to his primary educational institution [10].

The main objective of mobility in the sphere of physical culture and sports is to provide the student with an opportunity to get education in the chosen area of training, to provide him access to recognized centers of knowledge, to develop student's knowledge in the field of physical culture and sports.

As a result:

- students have the opportunity to choose an individual educational route, the better educational services;

- new conditions for effective competition and interaction are emerging for universities;

- the labor market becomes international, which subsequently facilitates the employment of qualified personnel.

- academic mobility in the Russian context implies cooperation not only with foreign universities, but also with Russian ones.

Instruments for the development of academic mobility are:

- European credit transfer system. The system originated in the framework of the European ERASMUS program in 1988. Comparability of the curricula allows students to choose programs that are relevant to the qualifications they receive, which are counted as passed material in their university;

- diploma supplement gives a complete de- 


\section{Теория и практика управления образованием}

scription of the subject, level, content of the training received. The application raises the level of academic mobility of students and the mobility of graduates in the labor market;

- double diplomas give students the opportunity to complete two higher educational institutions according to the developed joint academic program for one period of academic studies.

To coordinate the interaction of the sending and receiving universities in the European practice of mobility, the Learning Agreement was introduced as an official document.

A special function in the implementation of academic mobility is the management of this process.

The research of management as a phenomenon, including pedagogical, is devoted to a lot of scientific works, the generalization of which allows to treat management as [5; 6; 8, pp. 3-5]:

1) science - a system of ordered knowledge in the form of concepts, theories, principles, methods and forms of management;

2) art - the ability to effectively apply the management science data in a specific situation;

3) function - informational impact on people and economic objects, carried out with the purpose to direct their actions and get the desired results;

4) process - a set of managerial actions that ensure the achievement of the set goals by converting resources at the "input" into products at the "exit";

5) staff - a set of structures and people that ensure the use and coordination of all resources of social systems to achieve their goals.

The scientific extrapolation of the semantics of the term "management" for our research academic mobility - leads us to the conclusion that it is necessary to mean the principle of superposition in favor of the principle of improvement (universality) [11]. It implies the development (finding) of the most universal perfect methodology behavior of the subject of management.

The implementation of this principle, taking into account the specificity of academic mobility (the priority of interaction of all subjects of the educational process) is possible and appropriate in the participative management of this process.

In modern philosophical and cultural studies, participation is considered in the aspect of subject-object relations. In pedagogical studies there are several approaches to the interpretation of the term "participation", which means: - an alternative to authoritarianism, implemented in the following areas: seeking the consent of the future teacher. He attempts to identify and use the individual and collective wisdom of all members of the group; joint decision-making; effective delegation of rights; joint identification of problems and related actions for their solution; creation of conditions, attitudes, mechanism for improving cooperation between the teacher and students;

- joint solution of problems, participation of ordinary members of the organization in the planning and implementation of organizational changes $[3,4]$.

The term "participative management" implies various forms of participation of subjects of the educational process in management. In addition, participative management means the involvement of participants in this process in governance, that is, actors at all levels of the organization participate in setting goals, making decisions, analyzing and solving problems [7, 9].

The effectiveness of the use of participatory management largely depends on the correct use of its principles [12, p. 155-156]:

- the voluntary nature of participation in management through working in small groups or participating in surveys;

- constant assistance and support to the head of a small group, provision of information necessary for discussion;

- the work of participants in small groups should be regulated, there should also be regulations on other forms of participation (promotion of proposals, participation in cross-functional projects, etc.);

- absence of any sanctions for the nomination of ideas and proposals;

- all the developments should be considered, feedback on any idea is necessary;

- all ideas that have been approved should be implemented;

- any achievements of the participants in the process should be noted, it is necessary that the participants know which of their achievements proved to be valuable and the movement in which direction is good.

The main forms of participation in participative management are:

the first level is the nomination of proposals that can be put forward both individually and during group discussion (the so-called "problem seminar"). This level does not require the introduction of structural and other changes in the traditional organization of the process and can be carried out directly by the manager. 
the second level - the development of alternatives - requires the creation of special structures that can effectively solve this problem. In practice, this is expressed in the creation of temporary or permanent groups, which are assigned to perform a specific task.

the third level - the choice of alternative assumes that participation in management is carried out in the form of the work of special groups coordinating the various directions of work.

The mechanism of participative management can be scientifically justified taking into account the methodology of the participative approach, which is very close to the concept of "organizational development" [12].

The main mechanism for ensuring participation in participative governance is seen in the provision of the possibility of discussing problems and finding their solutions and in the introduction of the practice of regulating the ideas collection and proposals and the practice of creating interfunctional groups.

Consideration of the above mentioned provisions in the view of academic mobility in the sphere of physical culture and sports allows us to draw the following fundamental conclusions $[1,2]$.

The organization of interaction in the planning of academic mobility based on participative management supposes the implementation of an appropriate participative approach. It means such an orientation of research on this problem, which is represented by a set of methods that ensure the analysis, structuring and functioning of forms of joint activity of subjects of the educational process on the basis of co-management. The value of the participative approach is, in our opinion, the following:

a) ensuring integration in planning, implementing and diagnosing the process of academic mobility at the level of teacher and student comanagement;

b) the realization of the identification of students on the basis of the achievement of the state of participation.

\section{The conclusion}

Participative management of academic mobility in the sphere of physical culture and sport means: joint decision-making on the forms, ways and standards of academic mobility; the creation of a cultural mechanism for cooperation between the teacher and students; effective delegation of rights; actualization of the potentials of selfdevelopment of participants in the educational process in their polysubject dialogue.
Thus, the analysis shows that academic mobility is a way of developing and updating the educational process and educational programs of Russia's higher professional education. This makes it possible to avoid the closure of the Russian education system, to seek recognition of the curricula implemented by Russian universities on the European educational space, to ensure transparency and recognition of the competencies and qualifications of university graduates, the competitiveness of Russian educational programs on the world market of educational services. Despite the emerging problems, it is necessary to seek and develop various forms of academic mobility for students and teachers.

\section{References}

1. Barnes Meghan E. Encouraging Interaction and Striving for Reciprocity: The Challenges of Community-Engaged Projects in Teacher Education. Teaching and Teacher Education, 2017, vol. 68, pp. 220-231. DOI: 10.1016/j.tate.2017.09.004

2. Gurney L., Liyanage I. Managerialist vis-à-vis Learning and Development Goals for EAL Teachers: a Case Study of an in-Service Professional Development Provider. International Journal of Pedagogies and Learning, 2015, iss. 1, vol. 10, pp. 38-46. DOI: 10.1080/22040552.2015.1084675

3. Deming E. Vykhod iz krizisa. Novaya paradigma upravleniya lyud'mi, sistemami $i$ protsessami $=$ Out of the Crisis [Out of the Crisis. The New Paradigm of Managing People, Systems and Processes $=$ Out of the Crisis]. Moscow, Al'pina Publ., 2011. 400 p.

4. Dunkan D.U. Osnovopolagayushchie idei $v$ menedzhmente [Fundamental Ideas in Management]. Moscow, Delo Publ., 1996. 272 p.

5. Kibanov A.Ya., Zakharov D.K., Konovalova V.G. Etika delovykh otnosheniy [Ethics of Business Relations]. Moscow, INFRA-M Publ., 2002. $367 \mathrm{p}$.

6. Lafta Dzh.K. Teoriya organizatsii [The Theory of Organization]. Moscow, TK Velbi Publ., Prospekt Publ., 2006. 416 p.

7. Suvorova S.L. Formirovanie kommunikativno-diskursivnoy kul'tury budushchikh uchiteley. Diss. dokt. ped. nauk. [The Formation of Communicative-Discursive Culture of Future Teachers. Diss. Doct. (Pedagogy)]. Chelyabinsk, 2005. $380 \mathrm{p}$.

8. Peterson P.P., Fabozzi F.J., Habegger W.D. Financial Management and Analysis Workbook: 


\title{
Теория и практика управления образованием
}

Step-by-Step Exercises and Tests to Help You Master Financial Management and Analysis. Wiley Publ., 2004. 894 p.

9. Rolková M., Farkašová V. The Features of Participative Management Style. Procedia Economics and Finance, 23, 1383-1387. $2^{\text {nd }}$ Global Conference on Business, Economics, Management and Tourism, 2015, vol. 23, pp. 1383-1387. DOI: $10.1016 / \mathrm{S} 2212-5671(15) 00391-3$

10. Kontseptsiya akademicheskoy mobil'nosti $v$ Rossiyskoy Federatsii [The Concept of
Academic Mobility Development in the Russian Federation]. Available at: http://intpr.ntf.ru/Dsw Media/koncepciyaakademicheskoymobil-nosti_ itog.pdf (accessed 05.12.2017).

11. Vershigora E.E. Menedzhment [Management]. Moscow, INFRA-M Publ., 2007. $283 \mathrm{p}$.

12. Vorozheykin I.E. Upravlenie sotsial'nym razvitiem organizatsii [Management of Social Development Organization]. Moscow, INFRA-M Publ., 2001. 174 p.

Received 20 January 2018

УДК 378.037.1:005.1

DOI: $10.14529 /$ ped180105

ББК Ч448.4:Ч51

\section{ПАРТИСИПАТИВНЫЙ МЕНЕДЖМЕНТ АКАДЕМИЧЕСКОЙ МОБИЛЬНОСТИ СТУДЕНТОВ В СФЕРЕ ФИЗИЧЕСКОЙ КУЛЬТУРЫ И СПОРТА}

\section{С.Л. Суворова, И.С. Осипова}

Шадринский государственный педагогический университет, г. Шадринск, Россия

\begin{abstract}
В статье раскрывается актуальность проблемы поддержки академической мобильности студентов в сфере физической культуры и спорта, сущность партисипативного подхода к управлению данным процессом; анализируются понятия «партисипация», «партисипативное управление», «академическая мобильность»; характеризуется система принципов, положенных в основу партисипативного подхода к управлению процессом академической мобильности студентов. Представлены позиции ученых по вопросу реализации механизмов партисипативного управления процессом академической мобильности студентов.

Особое внимание уделяется практике реализации процесса академической мобильности студентов в сфере физической культуры и спорта на основе партисипативного управления. Авторы делают вывод: академическую мобильность можно рассматривать как средство развития и обновления образовательного процесса и образовательных программ высшего профессионального образования России.

Ключевые понятия: партисипативный подход, партисипативное управление, академическая мобильность, партисипативное управление академической мобильностью в сфере физической культуры и спорта.
\end{abstract}

\section{Лumepamypa}

1. Barnes Meghan, E. Encouraging interaction and striving for reciprocity: The challenges of community-engaged projects in teacher education / E. Barnes Meghan // Teaching and Teacher Education. - 2017. - Vol. 68. - P. 220-231.

2. Gurney, L. Managerialist vis-à-vis learning and development goals for EAL teachers: a case study of an in-service professional development provider / L. Gurney, I. Liyanage // International Journal of Pedagogies and Learning. - 2015. - Iss. 1, vol. 10. - P. 38-46.

3. Деминг, Э. Выход из кризиса. Новая парадигма управления людьми, системами и прочессами $=$ Out of the Crisis / Э. Деминг. - М.: Альпина Паблишер, 2011. - 400 c.

4. Дункан, Д.У. Основополагающие идеи в менеджменте / Д.У. Дункан. - М.: Дело, 1996. $272 c$ 
5. Кибанов, А.Я. Этика деловых отночений / А.Я. Кибанов, Д.К. Захаров, В.Г. Коновалова. М.: ИНФРА-М, 2002. - 367 c.

6. Лафта, Дж.К. Теория организащии / Дж.К. Лафта. - М.: ТК Велби, Проспект, 2006. $416 \mathrm{c}$.

7. Суворова, С.Л. Формирование коммуникативно-дискурсивной культуры будущих учителей: дис. ... д-ра пед. наук: 13.00.08 / С.Л. Суворова. - Челябинск, 2005. - 380 с.

8. Peterson, P.P. Financial Management and Analysis Workbook: Step-by-Step Exercises and Tests to Help You Master Financial Management and Analysis / P.P. Peterson, F.J. Fabozzi, W.D. Habegger. - Wiley, 2004. - 894 p.

9. Rolková, M. The Features of Participative Management Style / M. Rolková, V. Farkašová // Procedia Economics and Finance, 23, 1383-1387. 2 $2^{\text {nd }}$ Global Conference on Business, Economics, Management and Tourism. - 2015. - Vol. 23. - P. 1383-1387.

10. Конщепџия академической мобильности в Российской Федераџии. - http:// intpr.ntf.ru/ DswMedia/koncepciyaakademicheskoymobil-nosti_itog.pdf.

11. Вершигора, Е.Е. Менеджмент / Е.Е. Вершигора. - М.: ИНФРА-М, 2007. - 283 с.

12. Ворожейкин, И.Е. Управление социальным развитием организации / И.Е. Ворожейкин. М.: ИНФРА-М, 2001. $-174 \mathrm{c}$.

Суворова Светлана Леонидовна, доктор педагогических наук, профессор, и.о. заведующего кафедрой славяно-германской филологии, Шадринский государственный педагогический университет, г. Шадринск, alex97@shadrinsk.net.

Осипова Ирина Сергеевна, кандидат педагогических наук, доцент, заведующая кафедрой теоретических основ физического воспитания и безопасности жизнедеятельности, Шадринский государственный педагогический университет, г. Шадринск, i.s.osipova@mail.ru.

Поступила в редакцию 20 января 2018 г.

\section{ОБРАЗЕЦ ЦИТИРОВАНИЯ}

Suvorova, S.L. Participative Management of Academic Mobility in Physical Culture and Sport Activities / S.L. Suvorova, I.S. Osipova // Вестник ЮУрГУ. Серия «Образование. Педагогические науки». - 2018. - Т. 10, № 1. C. 37-41. DOI: $10.14529 /$ ped180105

\section{FOR CITATION}

Suvorova S.L., Osipova I.S. Participative Management of Academic Mobility in Physical Culture and Sport Activities. Bulletin of the South Ural State University. Ser. Education. Educational Sciences. 2018, vol. 10, no. 1, pp. 37-41. DOI: 10.14529/ped180105 